\title{
PERTANGGUNGJAWABAN PIHAK GOJEK ATAS KERUGIAN YANG DIDERITA KONSUMEN DALAM HAL PENYELENGGARAAN PENGANGKUTAN BARANG
}

\author{
I Made Pratitha Adi Putra, I Nyoman Putu Budiartha. Ni Gusti Ketut Sri Astiti \\ Fakultas Hukum Universitas Warmadewa, Denpasar-Bali, Indonesia
}

\begin{abstract}
Abstrak
Fenomena Go-Jek merupakan inovasi dari fenomena pengangkutan konvensional karena bukti dan/atau dokumen pengangkutannya berbentuk dokumen elektronik, sehingga perlu diketahui bagaimanakah pertanggungjawaban pengangkut atas kerugian yang diderita oleh konsumen (pengguna jasa) dalam pengangkutan barang oleh pengusaha PT. Go-Jek Indonesia dan upaya hukum yang dapat dilakukan oleh konsumen. Penelitian ini bertujuan untuk menjeaskan pertanggungjawaban pengangkut atas kerugian yang diderita oleh konsumen (pengguna jasa) dalam pengangkutan barang oleh pengusaha PT. Go-Jek Indonesia dan menganalisis hukum apakah yang dilakukan oleh konsumen (pengguna jasa) terhadap pengangkut atas kerugian yang dideritanya. Jenis penelitian yang digunakan adalah tipe penelitian hukum normatif yang dilakukan dengan metode pencatatan dan pengkajian berdasarkan bahan-bahan hukum. Data diperoleh dengan cara mengumpulkan informasi melalui buku-buku ilmu hukum tanpa melenceng dari hukum positif demi merangkai sebuah kesimpulan, oleh karena itu maka yang mejadi sumber data adalah data primer dam sekunder. Hasil penelitian menunjukkan bahwa Mekanisme pertanggungjawaban pemberian ganti kerugian terhadap konsumen karena kesalahan pelaku usaha maka PT. Go-Jek Indonesia memberikan jaminan dan/atau garansi atas jasanya melalui syarat dan ketentuan yang telah tercantum di dalam website resminya yang memberikan maksimal Rp. 10.000.000,-. Upaya hukum yang dapat dilakukan oleh konsumen terhadap pengangkut atas kerusakan yang dideritanya yakni sesuai dengan ketentuan Undang-Undang Perlindungan Konsumen.
\end{abstract}

Kata kunci: Pertanggungjawaban Gojek; Kerugian Konsumen; Pengangkutan Barang

\begin{abstract}
The Go-Jek phenomenon is an innovation from the conventional transportation phenomenon because the evidence and / or transportation documents are in the form of electronic documents, so it is necessary to know how the transporter is responsible for losses suffered by consumers (service users) in the transportation of goods by PT. Go-Jek Indonesia and the legal remedies that consumers can take. This study aims to explain the transporter's responsibility for losses suffered by consumers (service users) in the transportation of goods by PT. Go-Jek Indonesia and analyze what laws are done by consumers (service users) to carriers for the losses they have suffered. The type of research used is the type of normative legal research which is carried out by the method of recording and reviewing based on legal materials. Data is obtained by collecting information through legal science books without deviating from positive law in order to form a conclusion, therefore the data source is primary and secondary data. The results showed that the responsibility mechanism for giving compensation to consumers due to the mistakes of business actors, PT. Go-Jek Indonesia provides guarantees and / or guarantees for its services through the terms and conditions listed on its official website which provides a maximum of IDR. 10,000,000, -. Legal remedies that can be taken by consumers against carriers for the damage they have suffered are in accordance with the provisions of the Consumer Protection Law.
\end{abstract}

Keywords: Gojek Accountability; Consumer Losses; Goods Transportation

\section{PENDAHULUAN}

Negara Indonesia merupakan Negara dengan kepadatan penduduknya yang tinggi, berbagai aktivitas dilakukan setiap hari diberbagai tempat sampai waktu tertentu sehingga susah melakukaan aktifitas ekonomi (Devi et al., 2016). Negara yang pulaunya terpisah satu sama lain membuat setiap pekerja tidak bisa melakukan pekerjaan secara individu atau sendiri, maka dibutuhkan tenaga bantuan semisal angkutan umum yang bertugas mengantar atau menjemput pelanggan berangkat dari satu lokasi ke lokasi lainnya, pekerjaan sebagai angkutan umum selain mempermudah pekerjaan setiap masyarakat namun juga pekerjaan menguntungkan antara para pihak yang terlibat baik dari penumpang maupun pengemudi angkutan umum. Berbagai jasa ditawarkan oleh angkutan umum mulai dari mengantar makanan minuman, barang titipan serta mengantar sesama ke lokasi yang 
ditentukan penumpang. Perkembangan zaman mendesain segala sesuatu dengan canggih sehingga sekarang sudah banyak pengguna angkutan umum bekerja sama dengan perusahaan elektronik yang memudahkan para pengemudi angkutan bertemu langsung dengan pelanggan melalui jaringan internet, penumpang tinggal memesan kebutuhan yang diperlukan tanpa menunggu lama pengguna angkutan datang menghampiri. Harga angkutan umum menyesuaikan tujuan penumpang atau keperluan yang dibutuhkan pemesan (Muhammad, 2008).

Terkenalnya penggunaan aplikasi online yang mempermudah masyarakat dalam melakukan kegiatan membuat perusahaan angkutan umum online kian terkenal dan membuat banyak lapangan kerja baru bagi masyarakat yang lama menganggur, tidak susah bergabung diperusahaan asal memenuhi ketentuan yang diberlakukan perusahaan semisal pengemudi harus memiliki kendaraan sendiri dan jujur, lalu pihak perusahaan mendaftarkan nomor kendaraan ke aplikasi yang terhubung ke semua pengguna aplikasi. Pemerintah mengapresiasi perusahaan angkutan online karena mengurangi angka pengangguran di Indonesia serta membuat pemasukan bagi negara melalui pajak perusahaan, permintaan dari pemerintah agar semua bagian dari perusahaan selalu jujur saat bekerja, tidak menyepelekan pekerjaan serta teliti, karena jika terjadi satu permasalahan membuat keseimbangan perusahaan menjadi terganggu dan nama perusahaan menjadi rusak di mata masyarakat. Sebagai pemilik harus selalu mengawasi dan memberikan edukasi kepada pengemudi angkutan umum agar mementingkan kepentingan pelanggan dan komunikasi baik dengan perusahaan demi menghindari adanya tuntutan pelanggan karena tidak puas dengan jasa angkutan umum.

Perusahaan angkutan online yang terkenal di Indonesia dinamakan Go-Jek, merupakan perusahaan yang awalnya hanya mencoba keberuntungan namun sekarang menjadi langganan masyarakat membuat penghasilan perusahaan ini tidak main-main, termasuk salah satu perusahaan penyumbang pajak terbanyak di Indonesia. Semua masyarakat bisa bergabung bersama Go-jek baik menjadi pengemudi atau sebagai pelanggan dengan mengunduh aplikasi yang ada pada telpon masing-masing. Sangat mudah menggunakan aplikasinya karena setiap melakukan pemesanan pengemudi online akan menghubungi pelanggan guna meyakinkan pesanan agar tidak terjadi kesalahan saat transaksi (Suryaningsih, 2019). Saking besar nama perusahaan ini membuat banyak pengangguran memiliki pekerjaan tersebar diberbagai penjuru negara bahkan banyak restoran dan tempat usaha lainnya yang bekerja sama dengan Go-jek guna mempermudah masyarakat mencari dan menemukan pesanannya di satu aplikasi. Semua ada di aplikasi Go-Jek mulai dari kuliner, swalayan untuk memenuhi kebutuhan sehari-hari, jasa antar barang tanpa perlu keluar rumah, pembayaran internet dan pulsa serta masih banyak lagi, seolah masyarakat terbius dengan aplikasi yang bisa dikatakan sangat mengerti kebutuhan masyarakat. Berdirinya perusahaan ini membuat semakin berat persaingan perusahaan-perusahaan menarik minat masyarakat, banyak juga perusahaan serupa namun tidak sama yang menawarkan jasa pengiriman dan sejenis lainnya namun seolah sudah menjadi prioritas masyarakat. Menurut (Wahid \& Puspita, 2017) Perusahaan Go-jek tetap menjadi yang teratas dalam menarik minat masyarakat menggunakan jasa angkutan online.

Go-Send menyediakan kurir seketika selama 24 jam yang dapat dilacak keberadaannya setiap waktu baik kurir maupun barang saat melakukan pengiriman barang serta tanpa adanya batasan jarak dalam satu area sehingga instan, praktis, cepat, aman dan murah dapat dirasakan oleh konsumen. Akan tetapi, pengangkutan barang tidak hanya mementingkan kecepatan dan ketepatan alamat dan waktu pengiriman, namun aspek kondisi keselamatan barang konsumen atau tidak terjadinya kerusakan barang selama pengiriman hingga sampai di tangan konsumen merupakan hal terpenting. Semakin maju sebua kota mendorong perubahan perilaku konsumen terhadap kepraktisan, kemudahan, kecepatan, ketepatan dan keamanan dalam bertransaksi. Pengiriman barang menjadi mudah dengan hadirnya Go-Send di Kota Denpasar. Dilihat dari kepraktisan, kemudahan, kecepatan, ketepatan dan keamanan dari sisi keterlacakan maka Go-Send mampu memenuhi kebutuhan konsumen dalam pengiriman barang, akan tetapi aspek keamanan barang tidak hanya dilihat dari keterlacakan barang dan kurir tersebut selama pengiriman namun juga dari kondisi barang tersebut apakah sama dengan kondisi awal saat pengiriman yang berarti tidak mengalami kerusakan.

Berdasarkan hasil observasi awal terhadap 10 informan yang merupakan pengguna jasa Go-Send menunjukkan bahwa barang yang mereka kirimkan ke pembeli tidak sesuai dengan kondisi awal. ada beberapa kejadian-kejadian yang terjadi dalam angkutan jasa online mulai dari 
keterlambatan dalam pengiriman dokumen penting, tidak mengambil barang pengirim tanpa kejelasan, tidak jarang pula barang yang dikirim konsumen tertukar dengan konsumen lain maupun barang sampai di tempat tujuan dengan keadaan yang tidak lagi sama dengan kata lain rusak, bahkan ada yang menggunakan layanan Go-Send untuk mengantar handphone tidak sampai alamat tujuan dan driver Go-jek hilang jejak. Seperti kejadian tersebut di atas jelas merugikan konsumen pengguna jasa baik si pengirim maupun si penerima. Hal ini membuktikan bahwa penyelenggaraan pengangkutan yaitu PT. Go-Jek Indonesia dengan layanan Go- Send tidak memperhatikan keselamatan barang milik konsumen.

Penelitian terdahulu mengungkapakan bahwa Perlindungan hukum bagi penumpang juga diberikan melaui UU Perlindungan Konsumen, untuk melindungi dan memenuhi hak konsumen (Fillaili, 2019). Pengangkutan barang melalui jasa Go-Send adalah menjadi tanggung jawab apa bila terjadi kerusakan karena kesalahan dengan memperhatikan asas corporate liability, yaitu suatu korporasi/perusahaan dianggap bertanggung jawab atas kesalahan yang dilakukan oleh bawahan/orang yang berada di dalam pengawasannya yang menimbulkan kerugian pada orang lain (Mahfiroh, 2020). Walaupun ini sudah jauh sebelumnya persolan tentang perlindungan konsumen, namun diketahui sampai sekarang masih terdapat permasalah yang dialami oleh konsumen. Oleh sebab itu Penelitian ini bertujuan untuk menjeaskan pertanggungjawaban pengangkut atas kerugian yang diderita oleh konsumen (pengguna jasa) dalam pengangkutan barang oleh pengusaha PT. Go-Jek Indonesia dan menganalisis hukum apakah yang dilakukan oleh konsumen (pengguna jasa) terhadap pengangkut atas kerugian yang dideritanya

\section{METODE PENELITIAN}

Penelitian didesain menggunakan penelitian hukum normatif yaitu hukum kepustakaan yang mengacu pada norma hukum yang terdapat dalam peraturan Perundang-undangan. Pendekatan perundangan-undangan adalah melakukan suatu penelitian dengan berpatokan pada undang-undang sebagai dasar dalam penelitian ini. Pendekatan kasus dilakukan guna melihat, mencatat dan memahami permasalahan yang diangkat dalam penelitian ini dengan tidak keluar dari zona hukum positif (Waluyo, 2002). Adapun sumber data yang dihunakan adalah data hukum primer dan sekunder. Metode penelitian yang digunakan adalah normatif dan kualitatis dimana dalam pengerjaannya menelaah isu hukum dengan didasari peraturan -peraturan hukum Perbankan di Indonesia (Ahmad, 2008)

\section{HASIL DAN PEMBAHASAN}

\section{Tanggung Jawab Pengangkut atas Kerugian yang Diderita oleh Konsumen (pengguna jasa)} dalam Pengangkutan Barang oleh Pengusaha PT. Go-jek

PT. Go-Jek Indonesia menggunakan jenis kendaraan bermotor yaitu sepeda motor untuk mengirimkan barang bertentangan dengan PP No. 74 Tahun 2014 karena pengangkutan umum yang dilakukan dengan tujuan komersial (menarik bayaran dari penumpang atau dari pengirim/penerima barang) tidak dapat menggunakan semua jenis kendaraan sebagaimana ditentukan Pasal 3 PP No. 74 Tahun 2014. Memiliki armada kendaraan bermotor seperti sepeda motor dan mobil membuat pimpinan perusahaan melindungi pengemudinya dengan perundang-undangan yang membuat setiap pengemudi merasa aman saat mengemudi mengantar atau menjemput pelanggan. Peraturan ketat diberlakukan kepada setiap pengemudi yang bergabung bersama mulai dari pembagian hasil sampai fasilitas yang diperoleh pengemudi, sanksi bagi pengemudi yang sengaja melalukan pelanggaran semisal mengambil barang pesanan milik pelanggan maka perusaan tidak bertanggung jawab dan menyerahkan sepenuhnya kepada pihak berwenang.

Setiap orang baik pengemudi dan pelanggan berhak mendapatkan perlindungan hukum saat melakukan transaksi dalam bentuk apapun. Banyaknya promo setiap hari membuat masyarakat menjadi tertarik menggunakan jasa perusahaan ini seperti gratis jasa pengiriman atau diskon beberapa persen dari tempat pelanggan membeli barang. Hak dan kewajiban para pengemudi ditentukan perusahaan kewajibannya mengutamakan kepentingan pelanggan dan menjaga kepercayaan dengan baik, haknya mendapatkan upah lebih banyak dari pada perusahaan. Bagi pelanggan berhak mendapatkan pelayanan dari pengemudi angkutan online sebaik mungkin dan jika terjadi kesalahan diakibatkan pengemudi dalam menjalankan tugas maka dapat membuat pengaduan ke kantor Gojek namun jika kesalahan ada pada pelanggan maka pihak Go-jek berhak menuntut pelanggan atas 
tuduhan pencemaran nama baik serta kewajiban pelanggan membayar tarif yang sudah diketahui saat memesan barang atau jasa melalui aplikasi (Widjaja, 1989).

\section{Perlakuan Hukum yang Dilakukan oleh Konsumen (Pengguna Jasa) Terhadap Pengangkut Atas Kerugian yang Dideritanya.}

Segala permasalahan yang membuat pelanggan menjadi resah atau tidak mendapat kepuasaan saat menggunakan aplikasi merupakan tanggun jawab perusahaan, perusahaan segera menindaklanjuti aduan pelanggan terkait ketidakpuasan yang dialami, pengemudi online terkait diminta penjelasan serta pertanggungjawaban guna meluruskan permasalahan setelah tidak ditemukan titik terang maka perusahaan menyerahkan permasalahan ke pihak berwajib. Terlihat menjadi pengemudi ojek online terkesan mudah namun memiliki tanggung jawab besar karena menjaga barang dan mengantarkan dengan utuh sampai tujuan. Saat terjadi konflik antara pelanggan dengan pengemudi pihak perusahaan sebisa mungkin mencari titik tengah permasalahan tanpa memihak pada kedua belah pihak demi menjaga citra perusahaan di mata masyarakat dan menjaga kepercayaan pemerintah pada perusahaan. Ganti rugi barang pesanan pelanggan menjadi tanggung jawab perusahaan sembari menunggu hasil sidang dari pengemudi yang dengan sengaja melakukan perbuatan kejahatan.

Hubungan yang terlaksanakan akibat adanya hak dan kewajiban pada salah satu pihak yang lain hubungan ini dapat dilaksanakan apabila dilakukan antara dua orang atau lebih yang dinamakan Hubungan hukum (rechtsbetrekkingen). Salah satu perusahaaan transportasi online mengembangkan tranportasi biasa dengan kemajuan teknologi menggunakan media internet atau biasa disebut dengan Online dalam lingkungan angkutan orang atau jasa memiliki dua pihak untuk membuat perjanjian yakni dari perusahaan tranportasi online dan konsumen atau pemakai jasa tersebut. Perjanjian tersebut juga memiliki objek tersendiri ialah didasarkan dari lingkungan untuk transportasi yang tata cara pemesanan atau prosedurnya dilakukan secara online serta menyangkut dengan hak dan kewajiban bagi masing-masing pihak yang terkait. Perusahaan tranportasi online maupun pengguna jasa angkutan (Sidabalok, 2014).

Perusahaan angkuntan konvensional memiliki beberapa hak dan kewajiban yang harus di penuhinya misalkan dalam haknya ia mendapatkan ongkos atau tarif dari pengemudi transportasi online yang telah bekerjasama dengan perusahaan tersebut sehingga setiap harinya ia mendapatkan setoran ataupun keuntungan, sedangkan dalam kewajibannya ia harus memberikan fasilitas yang nyaman bagi pengguna jasa tranportasi online tersebut dalam pelayanan jasanya yang telah di pesan oleh pengguna jasa transporasi online tersebut. Selain itu, konsumen memiliki juga hak dan kewajibannya dalam pelaksanaan layanan transportasi online tersebut. hak yang harus didapatkan oleh pengguna jasa transportasi online tersebut ialah mendapatkan fasilitas yang aman dan nyaman dalam setiap transaksinya hal ini tidak juga luput dalam kewajiban yang harus dipenuhi oleh konsumen yakni untuk membayarkan ongkos atau taruf setiap konsumen telah menyelesaikan transaksinya serta dapat memberikan penilaian kepada setiap pengemudi yang telah ditumpanginya.

Perusahaan Go-Jek kuat dibidang informasi dan komunikasi, melalui aplikasi perusahaan memasarkan barang dan jasa, merupakan suatu yang baru ada di Indonesia, menjadi sorotan pemerintah karena dengan sekejap mampu menjadi perusahaan yang banyak mengungguli perusahaan lain yang dikatakan sudah menjadi pilar ekonomi di Negara.

Perjanjian yang terjalin pada perusahaan sangat rapi karena berlangsung begitu saja saat sebuah telfon menerima pesan bahwa ada pesanan kelokasi tertentu. Para pengemudi dengan mudah mempelajari sistem yang dibuat perusahaan membuat sangat mudah dalam menjalankan pekerjaan demi mencukupi kebutuhan pribadi maupun keluarga. Setiap hari setiap orang memesan jasa menggunakan aplikasi Go-Jek, setiap wilayah sudah terdaftar banyak sekali pengguna aplikasi baik sebagai driver maupun pelanggan.

Penipuan dalam dunia bisnis. PT. Go-Jek Indonesia berbentuk perseroan terbatas yang diisi dengan struktur pemegang saham, komisaris dan direksi yang harus teruji dan terbukti kredibilitasnya akan dipandang sebagai perusahaan bonafide oleh calon mitra bisnis atau calon konsumennya. Ilmu hukum mengajarkan bahwa suatu hukum materil yang berlaku disuatu Negara dilaksanakan dan dipertahankan oleh hukum formil. Apa bila terdapat pelanggaran terhadap peraturan yang dibuat pemerintah terkait aturan yang mengikat suatu perusahaan, hukum formil yang berwujud hukum acara (merupakan peraturan hukum yang terbagi dua pidana maupun perdata) menjadi senjata mempertahankan hukum materiil. Demikian terkait sengketa yang terjadi saat melakukan transaksi 
online atau antara pelanggan dan pengemudi, hukum acara menjadi dasar hukum untuk mempertahankan hak-hak baik dari pihak pengemudi atau pihak pelanggan yang dilanggar oleh pihak lain melalui penyelesaian penuntutan kepada pihak yang melanggar agar mendapatkan ganjaran yang pantas dan melakukan kewajibannya sesuai perjanjian elektronik dan ketentuan-ketentuan hukum positif yang berlaku saat ini.

\section{SIMPULAN DAN SARAN}

\section{Simpulan}

Berdasarkan analisis data, dapat disimpulkan bahwa Mekanisme pertanggungjawaban pemberian ganti kerugian terhadap konsumen karena kesalahan pelaku usaha maka PT. Go-Jek Indonesia memberikan jaminan dan/atau garansi atas jasanya melalui syarat dan ketentuan yang telah tercantum pada website resminya yang memberikan maksimal Rp. 10.000.000,-, juga telah diatur di dalam Kitab Undang-Undang Perlindungan Hukum Perdata, Undang-Undang Perlindungan Konsumen dan Undang-Undang Lalu Lintas dan Angkutan Jalan yang kedua Upaya hukum yang dapat dilakukan oleh konsumen terhadap pengangkut atas kerusakan yang dideritanya yakni sesuai dengan ketentuan Undang- Undang Perlindungan Konsumen, Undang-Undang Lalu Lintas dan Angkutan Jalan dan Undang-Undang Informasi dan Transaksi Elektronik. Ketentuan-ketentuan tersebut telah mengatur dan menjamin bahwa setiap orang yang dirugikan dapat menuntut ganti kerugian dan menyelesaikan perkaranya baik melalui litigasi yakni mengajukan gugatan di dalam pengadilan ataupun non litigasi yakni menyelesaikan sengketa di luar pengadilan melalui arbitrase, atau lembaga penyelesaian sengketa alternatif lainnya sesuai dengan ketentuan Peraturan Perundang- Undangan.

\section{Saran}

Adapun yang disarankan oleh peneliti yaitu Kepada PT. Go-Jek Indonesia sebagai salah satu inovasi dalam dunia transportasi yang bergerak di bidang pengangkutan jasa transportasi barang, diharapkan selalu tunduk dan patuh terhadap Peraturan Perundang-Undangan yang mengatur mengenai jasa pengangkutan yang berlaku di Indonesia, guna menjamin keamanan, keselamatan dan kenyamanan konsumen, yang kedua Kepada pemerintah diharapkan agar segera menetapkan suatu produk hukum terkait standarisasi jasa transportasi online sehingga perusahaan jasa transfortasi online yang ada di Indonesia memiliki payung hukum yang jelas serta memberi perlindungan hukum bagi masyarakat pengguna jasa transfortasi online.

\section{DAFTAR PUSTAKA}

Ahmad, B. (2008). Metode Penelitian Hukum. Pustakasetia.

Devi, S., Fatchiya, A., \& Susanto, D. (2016). Kapasitas Kader dalam Penyuluhan Keluarga Berencana di Kota Palembang, Provinsi Sumatera Selatan. Jurnal Penyuluhan, 12(2), 144-156.

Fillaili, N. (2019). Tanggung Jawab Perusahaan Transportasi Online terhadap Penumpang Akibat Adanya Praktik Peralihan Akun Driver. Jurist-Diction, 2(4), 1375-1403.

Mahfiroh, R. (2020). Perlindungan Hukum terhadap Barang Kiriman Konsumen Pengguna Jasa Go-Send Instant Courier Melalui Tokopedia. Jurnal Lex Renaissance, 5(1), 235-249.

Muhammad, A. (2008). Hukum Pengangkutan Niaga. PT. Citra Aditya Bakti.

Sidabalok, J. (2014). Hukum Perlindungan Konsumen di Indonesia. PT. Citra Aditya Bakti.

Suryaningsih, I. B. (2019). Layanan Aplikasi Go-Jek: Validasi Skala Pengukuran Irsq Persepsi Konsumen pada Penggunaan Platform Go-Food. Bisma, 13(2), 112-121.

Wahid, U., \& Puspita, A. E. (2017). Upaya Peningkatkan Brand Awareness PT. Go-Jek Indonesia Melalui Aktivitas Marketing Public Relations. Jurnal Komunikasi, 9(1), 31-41.

Waluyo, B. (2002). Penelitian Hukum Praktek. Sinar Grafika.

Widjaja, G. (1989). Prinsip-prinsip Tanggung Jawab Pengangkutan. Rajawali. 